\title{
Considerații sintetice asupra originii și apariției limbajului uman
}

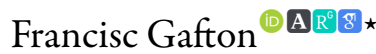 \\ Facultatea de Litere, Universitatea „Alexandru Ioan Cuza”, Bd. Carol I 11, 700506 Iași, România
}

\begin{abstract}
Despre articol
Istoric:

Primit 20 octombrie 2021

Acceptat 26 octombrie 2021

Publicat 12 decembrie 2021

Cuvinte-cheie:

originea limbajului

evoluție

comportament biosocial

plurimodal
\end{abstract}

\begin{abstract}
Rezumat
Limbajul uman (vocal-articulat) poate fi privit deopotrivă ca structură și organ, și ca instrument și comportament biosocial. Temelia sa este materială și motorie, iar dezvoltarea procesual-istorică. Examinînd relația dintre momentul inițial (gest) și rezultatul actual (limbaj vocal-articulat) - la nivelele motor și neuralse înțelege că activitățile mentale apar și se dezvoltă ca urmare a interacțiunilor organismului biologic cu mediul natural și social. Prin urmare, apariția sa nu se produce în consecința unei revoluții sau a unui salt evolutiv, ci ca urmare a unei dezvoltări organice și treptate, petrecute în mediu biosocial și avînd același tip de premise. La apariția sa au contribuit numeroase elemente (structuri osoase, musculare, nervoase, genetice) direcționate de evenimente sociale şi biologice care au produs comportamente, al căror exercițiu a condus la anumite dezvoltări.

Întrucît a generat o diversificare structurală și comportamentală și întrucît a putut servi evoluției, o astfel de dezvoltare a putut fi speculată de organismul biologic și social, astfel încît indiferent de spațiu, de timp, de elemente de context particular, de la un anumit nivel de dezvoltare încolo, diferitele comunităţi umane, răspîndite pe glob au prezentat tendința intrinsecă de a dezvolta această facultate.
\end{abstract}

„Prima sum: primatum nil a me alienum puto."

(Earnest Albert Hooton)

Respingere și negare. După ce generații de învăţaţi s-au străduit în încercarea de a desluşi geneza limbajului și a limbii, lingviștii-concentrîndu-se asupra unor considerente aflate în afara științei-au decis să elimine din căutările lor chestiunea genezei și apariției limbajului și a limbii, sub cuvînt că ea nu este de domeniul lingvisticii și, în fapt, nici nu interesează cercetarea științifică, fiind insurmontabilă și netrebuincioasă.

În felul acesta ei au respins calea firească a cercetării științifice, pătrunse de adevărul că pentru a înțelege realmente o entitate sau un proces, acestea trebuie studiate sub aspectele genezei și apariției, exersării și dezvoltării, funcționării, adaptării şi evoluției respectivei realități. Acest fapt a afectat organic: a) caracterul exhaustiv, profund și, în cele din urmă, real al cunoașterii; b) capacitatea lingvisticii de a înțelege cu adevărat limbajul și limba, spre a(-și) spori cunoașterea; c) relația lingvisticii cu științele care fac apel la și construiesc cu cunoștințe de încredere.

Pe de altă parte, în contextul în care în toate entitățile și procesele de care se ocupă științele sînt cu maximă dedicare cercetate sub aspectele amintite, atitudinea lingvisticii a provocat izolarea ei, întrucît eliminînd preocuparea pentru chestiunea originației, lingvistica nu s-a mai putut prezenta în fața științelor din amonte cu date care să poată fi înglobate în materialul întrețesut prin contribuția colectivă a științelor, ci, cel mult, cu date care rămîneau alături, întrucît vorbeau doar despre și pentru sine.

Chiar astfel, lucrurile ar fi rămas neschimbate, deoarece nevoile concrete ale lingvisticii păreau a fi satisfăcute de tipul de cunoaștere fragmentar și superficial pe care îl adoptase și care o caracteriza. Cu cîteva decenii în urmă, însă, cercetările din cadrul altor științe au ajuns în zona în care-pentru a progresa

*Adresă de corespondență: algafton@gmail.com. 
Francisc Gafton

în amploare și profunzime, dar și pentru a putea folosi cu încredere unele dintre datele a căror cercetare era în sarcina lingvisticii-aveau nevoie de lămurirea chestiunii genezei și apariției limbajului și a limbii. Acele științe continuau să rămînă neglijabil sau deloc interesate de cercetările, rezultatele și concluziile pe care lingvistica le oferea-fapt cît se poate de firesc întrucît, pe de o parte, multe dintre datele pe care le poate procură lingvistica nu servesc decît pentru a arăta că întregul exercițiu poate genera ceva, de cealaltă, întrucît rezultatele obținute fără a lua în seamă geneza și apariția nu pot fi decît incomplete (în cel mai bun caz) sau eronate (în mod obișnuit)—, interesul lor concentrîndu-se asupra originii și a proceselor constitutive ale limbajului și limbii. De aceea resetarea întregului proces a fost iniţiată tot de către cercetătorii aparținînd altor domenii ${ }^{1}$.

Accept și căutare. Într-o primă etapă, încercările de a afla factorii și cauzele apariției limbajului uman au mers pe căi unidirecționate, însă treptat s-a înțeles că limbajul uman nu apare în consecința unui singur factor ori a unei întîmplări biologice sau/și sociale, ci este rezultanta acțiunii unui mănunchi de factori și de evenimente, unele dezvoltate din altele, toate întrețesute la un moment dat și avînd rădăcini profunde și concrescute-evidente sau latente. Adică o evoluție ca aceea a limbajului nu poate decurge decît din coocurența mai multor stări și procese, devenite efecte și factori, înlănțuite și potențate reciproc, apoi generînd efecte în cascadă și convergente, dezvoltate și acționînd pe mai multe planuri-prin unele aspecte concurînd, prin altele colaborînd.

Prin urmare, încă de la începuturile sale, limbajul trebuie să fi fost rezultatul incipient al manifestării complexe a mai multor factori, avînd mai multe cauze și acționînd sub imperiul mai multor presiuni. Pe măsura exersării sale, dezvoltarea pe care a parcurs-o a fost secvențială, feluritele rezultante (inclusiv din categoria cauzelor și factorilor) generînd noi cauze, factori și efecte, mereu înmănuncheate și generatoare de noi modalități de existență și tipare de acțiune, mereu devenind într-o spirală coevolutivă. Este cît se poate de firesc, așadar, ca în diferitele momente ale constituirii, funcționării, răspîndirii, dezvoltării, consolidării și devenirii sale, unul sau altul dintre aspectele observate să fi avut o pondere sau o importanță conforme cu cerințele etapei parcurse. Rezultatul din diferitele momente, însă, nu putea fi generat decît de întregul complex de cauze și factori, sub întregul complex de presiuni. Pe măsura complexificării, factori şi cauze s-au maturizat, $s$-au născut și-deopotrivă, deși în măsuri diferite—au stimulat, au modulat și au hrănit dezvoltarea complexului comportament și produs secundar de natură biosocială.

Premisele apariţiei limbajului uman. Aflate sub imperiul unor nevoi, organismele dezvoltă capacitatea de a consuma energie de cantitate și calitate corespunzătoare, în vederea amorsării de procese producătoare ale unor modalități (fie și inițiale) de soluționare a acelor nevoi. Dezvoltarea unei modalități și a unui instrument de comunicare socială face parte din această categorie, iar mijloacele de soluționare a lor, precum și rezultatele concrete îmbină inextricabil factorii biologici cu cei sociali generînd și dezvoltînd lent, gradual și semiconștient un subprodus al evoluției biosociale a unei primate. Întreaga întreprindere naturală, dată, pe de o parte, de caracterul imperios al unei astfel de nevoi, iar de cealaltă de căile de obținere a rezultatelor, arată că limbajul uman a apărut prin poligeneză, adică trebuie să se fi dezvoltat relativ concomitent în sînul mai multor comunități, izolate unele de altele, începînd cu etapa în care dezvoltarea ființei umane și a comunității a cerut și permis acest fapt. Apoi, dezvoltarea iniţială nu putea fi nestingherită, continuă și de succes, aşa cum nici biologia, nici societatea și nici vorbirea vocal-articulată actuale nu sînt rezultatele unei prime constituiri care să fi reușit și să fi continuat neștirbit pînă astăzi. Dimpotrivă, în diferite spații trebuie să se fi produs felurite dezvoltări care au funcționat întrucîtva, după care au dispărut

\footnotetext{
${ }^{1}$ În cele ce urmează vom face o scurtă sinteză referitoare la geneza și apariția limbajului uman. Pentru a nu înșira bibliografia amplă și complexă care ne-a ajutat să studiem și să înțelegem această chestiune, vom trimite doar la unul dintre cei mai rîvnici propagatori ai importanței acestei chestiuni, și anume la Michael Corballis. Deși prezentările acestuia se sprijină pe o bibliografie amplă și de calitate, dată fiind complexitatea chestiunii, în relație cu caracterul concentrat al expunerii noastre, cele arătate de către Corballis, în articolele sale (2003, 2007, 2009a, 2009b, 2010, 2013, 2014a, 2014b, 2017), sînt augmentate cu date, observații și concluzii care ne aparțin, de asemenea procurate și fundamentate de ramurile biologiei (anatomie, fiziologie, embriologie, genetică, neurologie), paleontologie și de alte domenii care concură la lămurirea chestiunii (psihologie, sociologie, istorie).
} 
pierzîndu-se (uneori, poate, cu urme), continuitatea fiind una de proces, iar nu de rezultat concret. În sfîrşit, întrucît deopotrivă factorii și nevoile de ordin biosocial au continuat să acționeze în chip imperios, dezvoltările au reizbucnit și poate că iar s-au produs cedări și eșecuri, pînă într-o perioadă în care rezultatele au început să se stabilizeze și să se generalizeze în rîndul speciei.

Premise organice. Examinarea chestiunii la scară filogenetică arată că rolurile și funcțiile inițiale ale organelor care au ajuns să compună aparatul fonator erau legate de procese vitale fundamentale și necesare supraviețuirii (nutriție, respirație, percepție etc.), iar evoluția în anumite condiții și sub anumite presiuni, a unei anumite ramuri de hominizi, a cuprins felurite modificări (comportamentale, neurale, structurale, genetice) ce au dus la exaptări.

Exaptarea constituie un proces de reorientare—nu exclusivă—a rolului unei părți constitutive, în direcția îndeplinirii unei alte funcții decît cea inițială, eventual împreună cu care s-a dezvoltat respectiva structură. Exaptarea se referă la situația în care organismul adaugă noi funcții aceleiași structuri, eventual operînd mici restructurări adaptative. Ea diferă de adaptare, care se referă la situația în care, răspunzînd cu capacitățile sale unor nevoi adaptative (interne și/sau externe), organismul își creează mijloace adaptate pentru supraviețuirea în anumite condiții.

Un astfel de proces se petrece lent, fără abandonarea rolurilor și funcțiilor iniţiale, cu rezultate parțiale și cu relativa concordie a stărilor structurale și a celor funcționale. La rezultatele unei etape se ajunge gradat, cu prețul unor eforturi anevoioase, impuse de nevoi apărute ulterior și care pot înrîuri modificări anatomo-fiziologice în consecință. Privind la structurile anatomofiziologice articulatorii sau la cele neurale implicate în procesul comunicării, se constată că: a) „destinația” lor iniţială nu avea vreo legătură cu comunicarea; b) sînt atît de stratificate structuralfuncțional încît constituie rezultantele unor procese de devenire; c) sînt atît de complexe încît evoluția lor trebuie să se fi petrecut gradual, de-a lungul unei perioade de timp care depășește originile omului modern (maximum 2 milioane de ani).

Prin urmare, exercițiul interrelaționat al respectivelor elemente, coevoluția lor, dimpreună cu modificările funcționale rezultate au putut duce la conjugarea respectivelor componente și la adaptarea complexului rezultat, într-o direcție ce avea să permită un anumit comportament și o anumită utilizare a lor (comunicarea prin intermediul sunetelor vocal-articulate).

Bipedalismul. Pe parcursul producerii de achiziții evolutive, la nivel anatomic se petrec relativ des modificări morfo-structurale greu de explicat în ceea ce privește cauzele care au amorsat și determinat producerea lor, dar care, totodată, dețin potențialul de a aduce cu sine o cascadă de evenimente înlănțuite și reciproc potențate-prin sine și prin consecințele lor. Astfel este ridicarea homininelor pe membrele posterioare, fapt care probabil că se manifesta de la sporadic la frecvent, și care, întrucît a oferit foloase, a putut fi selectat evolutiv. În cazul lui Homo sapiens - la nivel ontogenetic și de la o anumită vîrstă-, bipedalismul s-a permanentizat (sau doar a ajuns dominant) și a devenit premisă a mai multor schimbări. Ca urmare s-au petrecut modificări, dezvoltări, adaptări și evoluții scheletale, cerebrale, circulatorii, respiratorii și digestive, afectate fiind practic toate organele, aparatele și funcțiile organsimului, precum și relațiile dintre ele. Întreaga înlănțuire cauzală a generat felurite consecințe relaționate, dintre care, aici, interesează—cu deosebire - trei: a) creșterea volumului cutiei craniene și a creierului; b) coborîrea laringelui și c) eliberarea membrelor anterioare.

Creșterea volumului cranian și a creierului. Instalarea bipedalismului a generat modificări adaptativ-evolutive ale tiparelor ontogenetice ale craniului, care au avut ca efect reorganizarea morfologică și diversificarea acestuia. Faptul s-a petrecut pe trei căi majore: a) modificarea dezvoltării prenatale a bazei craniene și a feței; b) mărirea ratei de creștere a craniului, în prima perioadă de după naștere; c) modificarea specifică a dezvoltării feței-toate trei reflectînd adaptarea la bipedalism, parcursul către un creier mare și adaptări de dietă. 
Fiind creierul organul prin excelență computațional, prin intermediul acestuia dobîndește organismul capacitatea de a sesiza similaritățile și deosebirile, de a clasifica, de a compune și descompune informația, de a concluziona și-pe aceste baze — de a pune în acțiune organele. Creșterea mărimii sale se datorează factorilor de mediu și dietei, factorilor de natură socială, modificărilor și dezvoltării canalelor senzoriale, simțuri mai competitive și abilități sporite avînd nevoie de un „gestionar” mai eficient, ceea ce—depăşit fiind un anumit prag evolutiv—implică un organ mai mare.

Cu toate că procesul de creștere a mărimii creierului însoțește apariţia și evoluția mamiferelor moderne, faptul nu se asociază cu necesitate de creșterea inteligenței ori a capacităţii intelectuale. Creșterea în complexitate a creierului implică în mod obiectiv modificări de volum, dar cuprinde cu necesitate maximă modificări structurale, cu consecințe funcționale. Sub acest aspect, numărul și natura sinapselor sînt mai importante decît numărul și natura neuronilor.

Aflată în relație coevolutivă cu creierul, comunicarea vocală—fie la mamifere, fie la păsări-necesită un creier în măsură să determine și să proceseze vocalizările specifice speciei. La capacitatea de a vorbi, aşadar, au participat cauze de ordin morfologic de la nivelul bazei craniului (compartimentarea componentelor, pozițiile relative, volumul, relațiile lor), însă nu capacitatea de comunicare a cerut un creier mai mare, ci creșterea creierului a permis dezvoltarea capacității de comunicare, abia ulterior fiind posibilă apariţia unor dezvoltări reciproc-stimulante.

Coborîrea laringelui. Constituirea aparatului fonator decurge din evoluții în plan structural ale unor componente-precum laringele, mandibula sau limba-, care au suferit adaptări, exaptări și dezvoltări funcționale care, ulterior au dobîndit roluri în vocalizare.

Atît sub aspect structural, cît și funcțional, laringele prezintă urme ale succesivelor modificări adaptative la mediu și la condițiile de viață, coevoluția dintre morfologie și activitate ducînd la adaptări morfologice ce-au dezvoltat funcția care, la rîndul ei, a încurajat evoluția structurii în sensul exaptării. În felul acesta laringele-sfincter care proteja plămînii unora dintre viețuitoarele acvatice-a devenit un organ capabil să permită un aport ridicat de aer, la o anumită viețuitoare ajungînd organ al vorbirii. Deși coborîrea laringelui nu constituie o trăsătură exclusiv umană—ea întîlnindu-se și la alte mamifere și primate—, în cazul ființei umane în stadiu adult—care prezintă laringele coborît în gît—ea este efectul unui răspuns adaptativ la solicitări lipsite de legătură cu vocalizarea propriu-zisă, dar de care aceasta a profitat.

Petrecute parțial în perioada evoluției hominide, schimbările poziționale ale laringelui au implicat funcții precum respirația, deglutiția, locomoția și vocalizarea, precum și unele schimbări evolutive ale acestor mecanisme, alături de schimbarea relaţiei dintre fonaţie și articularea în vederea vocalizării. Procesul are două etape: a) coboară scheletul laringal față de hioid-filogenetic, la strămoșii oamenilor și ai cimpanzeilor; onotogenetic la copii-și b) coboară hioidul față de mandibulă și de baza craniană, la oameni.

Poziționarea laringelui și a faringelui la primii hominizi era în partea superioară a gîtului, precum la actualele primate (exclusiv omul). O astfel de poziție permitea respirația și o bună așezare a epiglotei, necesară ingestiei de alimente, fără a periclita căile respiratorii, însă interzicea capacitatea de a modifica sunetele laringale. La naștere, ființa umană are o parte a echipamentului astfel poziționată încît este inaptă pentru producerea vorbirii. Faptul nu se datorează vreunui fel de economie (cum este cazul plămînilor lipsiți de aer, de pildă), ci arată că vorbirea este o achiziție recentă—care încă nu a trecut din ontogeneză în filogeneză. O achiziție nenecesară simplei supraviețuiri a vietății, un potențial care poate fi actualizat nu doar prin simplul exercițiu—precum multe altele—, ci după prealabile modificări structurale și morfologice.

Eliberarea membrelor anterioare. S-a văzut că trecerea la poziția bipedă a fost un proces petrecut lent, probabil cu pornire de la producerea ei accidentală și sporadică, trecînd prin adoptarea ei în anumite situații pentru care era potrivită și eficientă, și ajungînd treptat la asumarea ei deplină, cu pierderea adaptărilor proprii poziției patrupede. Tototdată, simpla producere și adoptare a poziției a adus cu sine infinit mai 
mult decît beneficiile ei prime și directe. Astfel, eliberînd membrele anterioare, bipedalismul a deschis calea întrebuințării acestora în alte scopuri decît sprijinirii și locomoției, iar modificînd poziția corpului a oferit posibilitatea fixării cu privirea a părții anterioare a corpului celuilalt (implicit a feței). Ambele rezultate au deschis calea valorificării și potențării mișcărilor corporale, în general, și oro-faciale, în special. Faptul că noile întrebuințări puteau fi profitabile—atît prin lărgirea spectrului de acțiuni posibile, cît și prin obținerea de noi atribute ale întrebuințărilor în sine-a putut creea premisa conjugării dintre adoptarea instinctivă și cea voită sau controlată a poziției bipede. În felul acesta, succesiunea operațiunilor a generat amplificarea lor, parcurgînd calea de la diversificare către rafinare.

Cascada de efecte, generată de instalarea bipedalismului și de exaptările astfel produse este deosebit de sugestivă dacă se observă că, plecînd de la utilizarea mîinilor, în vederea îndeplinirii unor acțiuni pentru care se întrebuințau alte părți ale corpului (adaptare), se trece prin operarea de noi acțiuni, pînă atunci imposibile sau nemaifăcute (exaptare) și se ajunge la operațiuni executate la nivele calitative nemaîintîlnite (perfecționare). Prin urmare, în consecința producerii unui fenomen urmat de modificări morfologice și structurale, și de funcționalizări în consecință, apoi ca efect al coevoluției dintre structură, funcție, întrebuințare și solicitări, de la o structură careprobabil—servea înotului, apoi sprijinului și deplasării terestre, apucării, apărării şi atacului, se ajunge la una care poate face toate acestea și încă multe altele (scriere caligrafică, pictură, cîntat la instrumente muzicale, felurite operațiuni artistice sau tehnice de infinită finețe), totul la un nivel de acuratețe și delicatețe continuu perfecționate.

Gestul. Felurite determinări organismale de ordin anatomic și funcțional arată că producerea de gesturi constituie un dat natural-mai mult decît aceea de sunete-care servește unor procese complexe şi importante pentru supraviețuire. Astfel, printre altele, gesturile sînt indispensabile procesului de învățare a feluritelor acțiuni (printre care și aceea a fabricării de unelte).

Este semnificativ și relevant faptul că, pentru un învățăcel lipsit de experiență, explicaţia orală este dificil de înțeles (sau, mai degrabă, de neînțeles), în vreme ce observarea acțiunii este edificatoare. Abia după acțiunea gestului poate deveni eficientă producerea de unelte. Ulterior, sub îndrumare combinată, gestul și cuvîntul vor colabora, se vor dezvolta și vor potența întregul complex de activități, prin rețeaua pe care o formează astfel, eventual coevoluînd. Aceasta arată prevalența temporală a comunicării gestuale asupra celei orale și înseamnă că activitatea de fabricare (a uneltelor) este strîns legată de cea de comunicare.

După cum se va vedea mai jos, primatele dețin un circuit neural activ deopotrivă cînd se produc și se percep mișcări (intenționate), fiind capabile să folosească intenționat flexibilitatea articulară a membrelor. Acest sistem le-a permis să obțină succese în învățarea și transmiterea comunicării gestuale. Comunicarea, aşadar, se întemeiază pe simptom și pe gestul natural—acte firești, dar deopotrivă capabile să dobîndească relevanță și semnificație-, ceea ce-i vădește bazele naturale și arată că limbajul—care nu se reduce la vorbirea articulată (și, implicit, nu decurge din chemările vocalizate)-începe cu posturile și gesturile primatei și se continuă cu chemările și cu vocalizările acesteia. Prin felul în care apare și se dezvoltă, precum și prin amplificarea treptată a efectelor sale, gestul este important deopotrivă filogenetic și ontogenetic, avînd implicații și consecințe de ordin social, în general participînd la evoluția culturală cumulativă și contribuind la desfășurarea acesteia.

Chiar astfel însă, cu toate că gesturile oro-faciale—cu complementul reprezentat de cele brahiale-, pot comunica一și, pe această bază, pot servi comunicării-, ele sînt limitative întrucît își îndeplinesc rolul numai dacă indivizii sînt destul de apropiați spațial și păstrează un contact vizual de calitate. Atît timp cît comunitatea nu este prea mare (cîteva zeci de indivizi), relația dintre nevoile și capacitățile ei de comunicare poate fi armonioasă, o astfel de soluție funcționînd. Creșterea numerică a grupurilor și a interacțiunilor din cadrul grupurilor mari face ca gestul—care nu este la fel de sesizabil, de nuanțat și 
de eliberator precum vorbirea—să nu mai satisfacă acele nevoi la un nivel mulțumitor. În plus, exercițiul gestual duce la pierderea valorii iconice a gesturilor mimate și la convenționalizarea lor, ceea ce deschide calea trecerii la simbolismul semnului lingvistic.

Această formă de miniaturizare, petrecută prin trecerea de la limbajul gestual la cel vocal, constituie o trăsătură comună animalelor și decurge din tendința naturală către economia de energie, fiind favorizată de caracterul eficient și util al noii modalități, dat fiind că astfel aparatul fonator preia povara comunicării, prin eliberarea mîinilor pentru alte activități.

Totuși, întrucît, la primate, controlul manual și facial este superior celui vocal, elementele de bază din fonologie (trăsăturile distinctive, elemente segmentale, silabe) nu apar ca urmare a naturii vorbite a limbii și nu se datorează exclusiv mișcărilor articulatorii. Ele se datorează mișcărilor faciale și manuale. Acestea înseamnă că limbajul vocal s-a dezvoltat dintr-un sistem care controla mișcările mîinii și ale feței. Vorbirea, adică, nu este un sistem de producere de sunete, ci unul de producere de mișcări articulatorii, la care concură acțiunea independentă a organelor articulatorii care constituie aparatul fonator, adică buzele, vălul palatin, laringele și părțile limbii (rădăcina, corpul și marginile ei). Vorbirea însăși este un sistem de gesturi ale limbii, buzelor și laringelui-ceea ce este în măsură, încă o dată să dea seama de faptul că întregul proces este unul de trecere de la o modalitate la alta și o formă de manifestare a evoluției.

Faptul că mișcările mîinii și ale aparatului fonator sînt relaţionate neural, filogenetic, precum și sub aspectele dezvoltării şi comportamentului, arată că gesturile aparatului fonator au fost încorporate în concertul gestual primordial, gesturile vizibile păstrîndu-și caracterul informațional, vocalizările evidențiind conținutul gestual. Posibilitatea de a folosi gestul ca mişcare articulatorie a facilitat apariția și adoptarea „vorbirii”, care răspundea creșterii: a) comunităţii, b) a frecvenței și intensității contactelor din sînul acesteia, c) a nevoii de precizie în comunicare. Consecința suprapunerii acestor mișcări este coarticularea, care face posibile două rezultate: rata ridicată a producerii și perceperii fluxurilor sonore.

Se observă astfel că trecerea de la limbajul gestual (vizual) la cel vocal (acustic) cunoaște grade. Caracterul simptomatic al gesturilor le face să fie implicite, apoi le face apte pentru a fi utilizate în comunicarea interindividuală (de la un producător către un anumit receptor), ceea ce le aşează la baza actului articulator, parcursul plecînd de la dominația gestului care doar este acompaniat de voce, apoi petrecîndu-se inversarea rolurilor, dar cu păstrarea combinației celor două (încă prezentă, puternică și chiar inextricabilă). Desigur, asocierea vorbirii la sistemul de comunicare de pînă atunci a amplificat forța de comunicare și a diversificat posibilitățile acesteia din urmă—cu creșterea necesităţii de a stăpîni bine sistemul. Acest proces s-a petrecut firesc, în consecința unei evoluții, probabil determinate de chipul în care s-a constituit pe cale evolutivă organismul, întrucît mișcările brahio-manuale, cele oro-faciale și cele oro-laringale sînt controlate de structuri situate în aria Broca (la celelalte primate aria F5), tot aici aflîndu-se unele mecanisme ce leagă percepția de producerea acțiunii.

Din cele ce preced se dezvăluie deja un aspect important pentru discuția de față, și anume caracterul plurimodal al creierului. Unele dintre impulsurile pe care le transmite acesta duc-la copii-deopotrivă la mișcări ale mîinilor și la gîngurit. Precum creierul, comunicarea-chiar în forma ei elaborată, vorbirea vocal-articulată—este de asemenea plurimodală (plurimodalitatea nefiind străină altor primate), o astfel de comunicare fiind susținută de dezvoltarea anumitor regiuni ale creierului (în special a celor parietale) și de relațiile acestora cu altele.

Neuronii-oglindă. Constituind o extensie naturală a acțiunii de recunoaștere, capacitatea mimetică este implicată în desfășurarea şi diversificarea a nenumărate procese ale dezvoltării și evoluției organismale și sociale. Primatele dețin un tipar neural provenit din ariile premotoare (generat prin observarea acțiunii și similar celui generat prin producerea acțiunii), care se constituie în mecanism fundamental de recunoaștere a acțiunii făcute de alții. În aria F5 a cortexului prefrontal al primatelor (mai puțin la om) și în aria Broca (la om) se află mecanismul care activează neuronii-oglindă. Acesta face ca în momentul în 
care stimulii vizuali furnizează percepții asupra unei acțiuni care, o dată acțiunea observată, se declanșează procesul de executare a respectivei acțiuni. Deși între cele două arii nu există identitate funcțională (la alte primate aria F5 coordonează mișcările musculare ale membrelor superioare, în relație cu un stimul vizual sau cu unul auditiv—neuroni-oglindă audio-vizuali—, în vreme ce la om, în aria Broca se află sediul care controlează mișcările articulatorii, în relație cu un stimul auditiv, controlul vocalizării fiind redus la celelalte primate), aici se află circuitele care leagă mîna de gură astfel încît, atunci cînd, concomitent, se apucă obiecte și se deschide gura, cele două deschideri sînt proporțional egale (în ambele sensuri: gura se deschide aproximativ pe mărimea obiectului apucat, iar mîna se deschide aproximativ pe deschiderea gurii). Activîndu-se deopotrivă cînd animalul face mișcări manuale, faciale și vocale, și cînd observă pe alții că le fac, neuronii-oglindă arată relația organică dintre acestea.

În continuare, consecutiv observației învăţate, nu doar simpla percepție, dar și gîndul în acea direcție poate stimula descărcarea energetică înspre acolo, ceea ce declanșează un răspuns adecvat față de comportamentul observat sau evocat mental. Petrecut prin intermediul neuronilor-oglindă, procesul indică relația strînsă dintre reprezentarea realității și vorbire. Observarea, apoi-deopotrivă dinspre actor și observator-, a faptului că un răspuns involuntar afectează comportamentul, duce la recunoașterea sau atribuirea unei intenții și la constituirea unui dialog; acesta constituie miezul limbajului. Fiind fundamental pentru empatie, înțelegere și imitaţie, în cazul oamenilor, mecanismul neuronilor-oglindă se extinde la învățare și la limbaj.

Cele de pînă aici arată că, fiind cuplate cu mecanismele învățării, structurile generice care acordă observarea acțiunii cu execuția ei au inițiat evoluția culturală a limbilor omenești. Depășind și înglobînd comunicarea oro-facială și pe cea brahio-manuală, limbajul vocal-articulat apare treptat ca rezultat al evoluției unui mecanism de bază care la origine nu era legat de comunicare: capacitatea de a recunoaște acțiunile. Fără a constitui o particularitate umană, sistemul gestual-manual a exploatat sistemul de potrivire al observației cu execuția și a netezit calea pentru evoluția sistemului de vocalizare deschis, numit vorbire.

Semi-abandonul comunicării prin semne și exercițiul în noua direcție au impus utilizarea de emisii sonore complexe (sunete combinatoriale), iar posibilitatea anatomică în această direcție a dus limbajul de la originile sale brahio-manuale la emisia de sunete. Treptat, gesturile își vor reduce din importanță, vocalizarea va căpăta autonomie, iar relația se va schimba, gestul devenind accesoriu (deși nu dispare, ci rămîne un însoțitor ce reflectă geneza întregii structuri funcționale - aşa cum anumite reflexe ori mișcări rămîn asociate între ele și dau seamă de relația lor genealogică și anatomo-fiziologică).

FOXP2 este o genă exprimată în multe regiuni ale creierului, fiind prezentă în forme proprii şi caracteristice în dotarea genetică a multor altor animale-de la reptile la oameni, ceea ce indică rolul important al acestui tip de gene, în creierele vertebratelor. Ea are numeroase roluri în dezvoltarea animalelor la care se află, indiferent de prezența sau absența vreunei relații cu învăţarea vocală imitativă.

La om, schimbările petrecute în diferitele regiuni ale creierului-conectate prin circuitele ganglionilor bazali, aflați în relație cu gena FOXP2—, împreună cu mutația acestei gene (foarte probabil supusă presiunilor evolutive și fiind țintă a selecției naturale) au favorizat apariția vorbirii (fără abandonul gesturilor). După cum o indică mai multe tipuri de date, FOXP2 este implicată în limbaj, dar nu este o nicidecum genă „a limbajului”. Aceasta nu doar întrucît (cu cîteva excepții notabile doar prin spectaculozitatea efectelor, dar nu și altminteri) nu există gene deținătoare ale unui rol unic și exclusiv, ci și întrucît ea este implicată în dezvoltarea creierului, în formarea circuitelor neurale cu acțiune regulatorie asupra capacităților motorii și cognitive, în funcționarea anumitor arii specifice (cu efecte asupra limbajului, vorbirii și cunoașterii), apoi în dezvoltarea plămînilor şi a esofagului, precum și în controlul expresiei altor gene.

Printr-o parte a complexului de acțiuni și de efecte pe care le aduce cu sine funcționarea ei, pentru discuția de față, gena FOXP2 este importantă deoarece a contribuit la coevoluția adaptărilor anatomice și neurale legate de vorbire și de bipedalism, fiind profund implicată în apariția și stabilizarea vorbirii. Totodată, ea este implicată în accelerarea învățării probabilistice a trăsăturilor limbii-pe calea segmentărilor elementelor de limbă și de acțiune-, facilitînd trecerea de la învățarea declarativă la cea procedurală, astfel adaptînd creierul la limbaj. 
Ganglionii bazali. Apariția și dezvoltarea ganglionilor bazali a constituit o modificare neurală importantă pentru achiziția și învățarea limbajului și a limbii. Ei au un rol important în cadrul funcțiilor cognitive superioare-printre care întărirea învățării și memoria procedurală—și al comportamentului emoțional. Deși marele rol al ganglionilor bazali se referă la controlul motor, întrucît funcția lor depășește planificarea și controlulul motor, ajungînd la inițierea, amplificarea și rafinarea semnalelor ce facilitează luarea deciziilor, ei sînt importanți pentru controlul asupra vocalizării. În copilările, rolul lor major constă în antrenarea tiparelor tractului vocal motor, iar la maturitate, în modularea emoțional-prozodică a enunțurilor.

Schimbările morfologice iniţiate de gena FOXP2, la nivelul ganglionilor bazali, au procurat baza fiziologică necesară capacităților senzoriomotoare necesare vorbirii articulate și au contribuit la reglarea fină a circuitelor corticale ale ganglionilor bazali. Faptul este relevant pentru achiziția și plasticitatea limbajului (deopotrivă la oameni și la păsări). Prin conexiunile cu cerebelul (implicat în anumite funcții cognitive, în actele de articulare, de segmentare a fluxului sonor și de control al coarticulației, și care conține circuite al căror rol este de a construi şi înmagazina pe termen lung reprezentări interne ale lumii generate pe cale lingvistică), ganglionii bazali participă la producerea și procesarea limbajului, fiind implicați în retroversiunea auditivă, adaptarea senzorio-motoare și învățare. Prin relațiile cu alte structuri nervoase ale creierului și datorită buclelor de circuit, ganglionii bazali capătă posibilitatea de a transmite informații astfel încît, prin conexiunile dezvoltate, să participe la comportamentele direcționate către un scop.

În ceea ce privește procesul de acomodare a mișcărilor laringale și supralaringale implicate în articulare, procesarea semnalelor de țin de evaluare și selecție, apoi învățarea motorie, ganglionii bazali au avut un rol crucial deoarece, prin intermediul acțiunii lor, exercițiul s-a putut fixa pe anumite coordonate, de asemenea rezultatele exercițiului, iar tiparele motorii ale vorbirii s-au automatizat. În sfîrșit, dată fiind relația dintre ganglionii bazali și variația comportamentală rapidă—legată de învățarea vocală—, apoi dintre prozodia supusă emotivității și cantitatea de dopamină, se vădește că ganglionii bazali au avut un rol major în cadrul noului tip de comportament de comunicare.

Toate acestea arată importanța ganglionilor bazali pentru procesul de comunicare lingvistică, la care contribuie în numeroase chipuri.

Socialitate și cooperare. Dotările biologice, modul de viață, exersarea şi evoluția adaptativă a acestora sînt în măsură să ducă la dezvoltarea pe căi proprii, a tiparelor comportamentale ale organismelor. La primate sînt comune capacitatea de a combina obiecte, de a construi și utiliza unelte și de a face toate acestea în modalități tot mai complexe, aceleași circuite și arii neurale guvernînd combinarea simbolurilor și utilizarea uneltelor. Desigur, nivelele de performanță diferă, fiind mult crescute în cazul lui H. sapiens.

Recursivitatea se referă la procesul prin care un procedeu computațional face apel la sine sau la un altul similar, și pare a distinge limbajul uman de formele de comunicare ale altor animale. În realitate, faptul că elementele se alătură și fuzionează sau se compun, astfel formînd structuri mai mari, care, la rîndul lor, urmează aceeași cale spre a genera structuri încă și mai ample, este unul universal și cunoaşte grade. Astfel, fractalii din lumea anorganică şi modularitatea din lumea organică și vie constituie specii ale aceluiași proces. La un alt nivel, un astfel de procescare poate fi numit în mai multe feluri, rezervarea unei denumiri nesemnificînd automat că se numește astfel o specie aparte și exclusivă a realităţii-este o caracteristică a mai multor tipuri de comportament uman (printre care și cel cogitațional) și nu se limitează la limbaj-căruia îi premerge $^{2}$. Totodată, deși se manifestă în gîndirea și în comportamentele speciei H. sapiens, recursivitatea nu constituie o prezență obligatorie în limbile naturale, adică nu este o condiție

\footnotetext{
${ }^{2}$ Asemănător, indiferent de denumire, conceptul care exprimă tendința de grupare (și, implicit, de separare), cumva, a materiei, se referă la acțiunea unei forțe care străbate deopotrivă materia nevie și pe cea vie (de la particulele elementare la societățile și la gîndurile umane). Firește că la diferitele nivele de organizare a materiei, acțiunea și efectele forței sînt diferențiate, însă indiferent de complexitatea nivelului, forțele de atracție și de respingere constituie instrumentele care duc la coeziunea celor asemănătoare sau identice structural, la adeziunea celor neidentice structural, la gregaritate, la (eu)socialitate etc.
} 
indispensabilă limbajului uman. Pe de altă parte, cu toate că în cazul fințtei umane cunoaște grade foarte avansate-dar nu pentru toate exemplarele speciei-, recursivitatea nu este interzisă altor animale, în lumile cărora există, aşadar.

Pe baza dovezilor procurate de studiul fosilelor și de paleontologie, se poate susține că viitorul H. sapiens sa desprins de celelalte hominide ale familiei acum aproximativ 7-8 milioane de ani, parcursul său evolutiv urmînd etape parțial asemănătoare, parțial proprii, dar, în esență, comparabile cu ale celorlalte ramuri derivate din aceleași trunchiuri succesive. Fie că continuau direcții de dezvoltare mai vechi, fie că inițiau unele noi, respectivele structuri funcționale (tipuri de organisme) aveau a răspunde, în chipul lor, acelorași solicitări de mediu (chiar dacă altfel resimțite), precum și cerințelor și tendinţelor interne. Acest fapt a putut duce la dezvoltarea unor atribute particulare, printre care se evidențiază gîndirea și limbajul, treptat căpătînd caracteristici proprii (ceea ce nu este același lucru cu unicitatea).

Din cele ce preced se mai înțelege că diferitele clase (precum mamiferele) și, apoi, ordine de animale (precum primatele) pot prezenta tipare structurale comune care, ulterior, pot cunoaște evoluții relativ comune, diferențiate, paralele și chiar divergente. Adică evoluția respectivelor structuri se petrece treptat și în continuitate. Astfel, de pildă, rețelele de circuite neurale ale primatelor şi ale rozătoarelor prezintă sisteme neurale frontale, temporale și parietale implicate în memorie autobiografică, imaginarea viitorului, dobîndirea de perspective asupra altora, adică elemente necesare existenței gîndirii și comunicării. Diferitele rezultate de etapă, dezvoltările și inovațiile pot fi de natură să caracterizeze și chiar să particularizeze specia, însă baza, precum și destule elemente de parcurs sînt comune și urmează liniile generale ale materiei vii, apoi pe cele ale clasei, ale ordinului, ale familiei, ale speciei, ale individului. Evoluția este contextualizată.

Pe baza acelorași tipuri de dovezi se poate arăta că aproximativ acum 2 milioane de ani, în Pleistocen, s-au petrecut schimbări de mediu destul de profunde, noile condiții aducînd cu sine noi solicitări și nevoi. Ca de fiecare dată, soluționarea acestora a venit din constituirea (prin reconfigurare și inovaţie) de noi comportamente, însă acest fapt nu a putut avea loc decît în consecința adaptărilor funcționale ale structurilor.

Rezultate precum cele pînă cum observate (bipedalismul și consecințele sale, creșterea în mărime și globularizarea cutiei craniene, creșterea în mărime, a creierului, complexificarea celei mai noi achiziții evolutive-cortexul一, felurite alte modificări neurale, exaptarea și rafinarea elementelor viitorului aparat fonator, apoi creșterea inervației limbii-nervul hipoglotal fiind mai bine reprezentat la oameni, în comparație cu primatele mari-, modificările în controlul respirației-regiunea toracică a coloanei vertebrale este mai mare la oameni decît la celelalte primate, alimentarea cu aer impusă de vorbire necesitînd mai mulți mușchi toracici și abdominali), au fost generate de răspunsurile organismelor biologice, în contextul complexificării structurilor și a vieții sociale, marele determinant fiind sporirea solicitărilor de mediu și apariția unora noi. La solicitările mediului acelei vremi răspunsul adaptativ-evolutiv a fost complexificarea prin concatenare și modularitate, iar tot ceea ce a urmat a fost permis de dezvoltarea echipamentului biologic. Apariția și, mai ales, exaptarea structurilor menționate, împreună cu consecințele astfel generate au dus la coevoluția lor, cu rezultate multiple, un astfel de răspuns contribuind la amorsarea proceselor care, prin evoluție graduală, au dus la apariția limbajului uman.

Apoi, unul dintre efectele și răspunsurile din plan social l-a constituit domesticirea, fenomen care s-a propagat și amplificat, atît în sine, cît și în efecte. Astfel, pe de o parte, contactul cu un semen domesticit înrîurește și amplifică propria stare domestică, de cealaltă stimulează atît convertirea unor situații competitive în colaborare (de pildă, creșterea comună a copiilor), cît și îmbinarea armonioasă a acestora (precum în cazul emulației reale). Achizițiile astfel dobîndite tind a fi utilizate în vederea constituirii unor funcții ulterioare, complexificate și corespunzătoare acelor stadii avansate. Produsele secundare ale procesului de domesticire și coevoluția adusă de aceasta oferă baze complexe pentru procesul de comunicare (în general), inclusiv pentru capacitățile de deprindere a celei vocale, adică a limbajului vocal-articulat. 
Mai mult decît în cazul celorlalte primate, datorită dezvoltării prin exercițiu tot mai solicitant, a dotărilor și performanțelor acestora, oamenii ajung să se distingă în ceea ce privește relația dintre diferitele emoții pe care le încearcă, crearea și utilizarea uneltelor, diferențierile corticale ulterioare creînd apoi capacități distincte, relativ modulare, pentru combinarea complexă de obiecte și pentru gramatică.

În acest cadru social de colaborare concurențială, limbajul vocal-articulat ajunge să ajute tuturor activităților umane, adică le stimulează dezvoltarea în anumite direcții. De aici se poate concluziona că la apariția sa, limbajul trebuie să fi fost parte a rețelei computaționale-motive care ar putea explica tendințele sale de a domina celelalte comportamente. Nici una, însă, dintre structurile implicate în limbaj și nici unul dintre efectele lor funcționale nu au fost pe de-a întregul responsabile de apariția limbajului, care a coevoluat cu alte capacități socio-culturale favorizate de evoluția biologică, sub presiunile solicitărilor de mediu, cerințelor și tendințelor interne. Nici o mutație și nici un salt nu puteau duce la un astfel de rezultat complex, ceea ce înseamnă nu atît că evoluționismul nu poate fi exclus din ecuație, cît că el este singurul care poate oferi explicația corectă a întregului complex de procese.

Mental time travel și theory of mind constituie două rezultate ale unor evoluții care participă la întregul complex. Cele două sintagme se referă la niște capacități pe care, iarăși, le întîlnim la destule mamifere și păsări, însă la H.sapiens, cunosc dezvoltări remarcabile.

Cercetările efectuate în acest sens nu puteau fi prea ample, profunde, detaliate și egale pentru toate speciile cercetate. Din acestea rezultă, pe de o parte, că respectivele atribute se înregistrează la $H$. sapiens, dar și la alte animale (unele mamifere, cu deosebire primate, și unele păsări), care dețin memorie episodică, imaginează urmări pentru evenimente și acțiuni, comportîndu-se astfel încît să determine urmările în sensul prevăzut, pe baza experiențelor trecute și a observării mediului, încercînd să provoace un viitor imaginat. Pe aceeași bază se mai poate afirma că, în cazul celorlalte animale, nu se întîlnește amplitudinea și nivelul de complexitate înregistrate la H. sapiens (datorită nivelelor sporite de recursivitate de care este capabilă ființa umană). De altfel, modalitatea curentă de comunicare, a ființei umane, se deosebește de aceea a altor animale, prin funcții gramaticale și sintactice, prin recursivitate și prin toate atributele care transformă un act în conversație.

În esență, cele două se referă la un complex prin care, pe baza experiențelor trecute și a observării celuilalt, se imaginează estimativ posibilități și acțiuni viitoare şi se sesizează ceea ce se petrece în mintea celuilalt, astfel ajungîndu-se la dobîndirea unei perspective asupra celorlalți-de asemenea bazată pe o rețea neurală complexă și exersată. Folosind călătoria mentală în timp se poate ajunge la înțelegerea biografiei altora, la ficțiune și la înţelegerea faptului că celălalt poate avea alte credințe și convingeri decît noi.

Călătoria mentală în timp și teoria minții premerg limbajului și probabil că au contribuit la apariția sa. Fiind potrivit pentru comunicarea de episoade (trecute, prezente, viitoare, planificate, fictive) și împărtăşind avantajele călătoriei mentale în timp, limbajul permite comunicarea a ceea ce este absent, printr-un sistem complex de concepte referitoare la obiecte, acțiuni, atribute etc., purtate de cuvinte, prin intermediul principiilor de combinare, sintaxa avîndu-și originea în combinația de concepte, spre a vehicula episoade.

Geneza limbajului. Din toate cele ce preced se pot desprinde destule elemente care să servească la a contura o imagine coerentă și de încredere, asupra chestiunii în discuție.

Structura ierarhizată și combinatorie a limbajului uman a evoluat începînd din Pleistocen, fiind o adaptare la necesitățile de comunicare, ce are a răspunde la și fiind în relație cu creșterea în complexitate a vieții sociale. $\mathrm{O}$ astfel de structură are capacitatea de a decupa elementele din care este construit mesajul, ceea ce favorizează apariția unui limbaj cu sintaxă—ca urmare a încorporării de structuri recursive-și solicită o memorie dezvoltată. Totodată, vorbirea articulată necesită modificări radicale la nivel neural, spre a obține controlul vocalizării. 
Distincția dintre limbaj și vorbire se sprijină pe faptul că semnele limbajului dețin toate trăsăturile esențiale ale limbajului (care a evoluat inițial ca sistem vizual, abia treptat încorporînd mișcări faciale și vocalizarea (care s-au autonomizat cîndva în ultimii 200000 de ani). Faptul este sprijint de dovezi care procurate de dezvoltare, de neurofiziologie și de arheologie.

Observînd situația altor primate-care dețin capacități remarcabile de a se angaja pe calea comunicării simbolice și nuanțate-se constată că limbajul nu este decît consecința unor dezvoltări evolutive ale unor structuri anatomo-fiziologice, care decurg din exerciţiul orientat de nevoi speciale. Faptul este arătat de anatomia și fiziologia aparatului fonator, de anatomia și fiziologia creierului, privite în relație cu limbajul (limba, laringele, etc., ariile Broca și Wernicke, și, în general, circuitele neuronale constitutive și conexiunile dintre ariile implicate în limbaj). Aceste dezvoltări, stimulate de interacțiunea cu mediul (așa cum se constituie și stabilizează ea la nivelul comunității concrete, adică în cadre culturale) se statornicesc și generează efecte.

Astfel, fabricarea uneltelor ducea la o tendință lateralizată spre stînga în vederea mișcărilor secvențiale, care s-a dovedit utilă limbajului, lateralizarea constînd în specializarea către și a două tipuri de sisteme de memorie, în stînga manifestîndu-se memoria activă pentru sarcini secvențiale (și, posibil de identificare), iar în dreapta memoria activă pentru sarcini legate de spațializare. Acest lucru arată că lateralizarea nu este consecința specializării ariilor cerebrale, ci a organizării respectivelor rețele neuronale, emisfera stîngă întărindu-și relațiile cu lobul frontal, iar cea dreaptă cu ariile implicate în văz.

Apoi, chemările primatelor, începînd cu cele involuntare-dezvoltate pe cale evolutivă—, depind de circuite neurale aflate în cel mai vechi sistem, și anume în cel limbic. În cazul H. sapiens, ca urmare a exercițiului, se va dezvolta un sistem separat, neocortical, care va opera prin tractul piramidal și se va lega prin sinapse direct de nucleii trunchiului cerebral, care răspundeau de comenzile către coardele vocale și limbă. Aceste schimbări au contribuit la creșterea controlului articulației și a discriminării perceptuale a sunetelor vorbirii, în esență la dominanța vorbirii asupra altor modalități de comunicare.

Prin urmare, dezvoltarea, de către organisme supuse anumitor solicitări de mediu, a unor seturi de echipamente biologice, a permis producerea, exersarea și dezvoltarea anumitor acțiuni și comportamente care au putut contribui într-o măsură copleșitoare la apariția unor funcțiuni complexe. Apoi, cu toate că limbajul este parțial determinat de cultură, vorbirea depinde de modificări biologice (alterările aparatului fonator, caracteristicile procesului de respirație, controlul neural asupra vocalizării), care sînt efecte ale manifestării selecției naturale, petrecute tot ca urmare a funcționării contextualizate cultural a unor organisme biosociale. Mai mult, precum alte capacități motorii complexe, nici vorbirea nu este înnăscută, ea apărînd pe cale evolutivă și fiind deprinsă treptat, prin procesul încercare / eroare.

Studiile efectuate la păsări-care deprind producerea vocalizărilor complexe, pe calea încercare / eroare - arată că procesul de învățare implică acțiuni avînd variabilitate exploratorie și de evaluare a performanțelor rezultate, în vederea dobîndirii de deprinderi motorii care duc la ameliorarea performanțelor acestei facultăți. Întocmai precum la oameni.

Toate acestea concură la a întări deducția că rădăcinile unui comportament complex precum este limbajul se află în întrețeserea și coevoluția dintre un organism biologic echipat cu felurite posibilități de dezvoltare și supus anumitor solicitări impuse de exerciţiul său amplificat, într-un mediu cu stimuli acționînd în anumite direcții. Acest fapt este cel care a dus la dezvoltarea și amplificarea acelor posibilităţi care, într-un mediu devenit tot mai solicitant a putut să se înscrie pe o spirală coevolutivă.

Dată fiind mulțimea, complexitatea și mai ales caracterul întrețesut al multor astfel de adaptări și exaptări evolutive, este limpede că acestea s-au petrecut gradat, dar și că primele rezultate au dus la unele forme de comunicare aflate în precedența celei actuale, adică în relație de proporționalitate cu cantitatea 
și calitatea rezultate în diferitele momente, cu plecare de la un limbaj gestual, însoțit de mișcări corporale și faciale, și ajungîndu-se la vocalizări articulate, dar fără dispariția fundamentului aflat în acel punct de plecare.

Așa cum felurite structuri anatomo-fiziologice, felurite procese - inclusiv gîndirea-au avut precursori la animalele de dinainte de H. sapiens și nu au apărut în urma unui salt—fie el și evolutiv—, nici limbajul nu apare în chip miraculos și care să nu poată fi explicat de știință. Cu toate că relaționează cu gîndirea, limbajul nu este o formă de gîndire (fie că decurge din experiență, fie din comunicare, gîndirea nu este același lucru cu limbajul care o exprimă și nu poate fi legată de vreun limbaj). După ce s-a constituit ca instrument de împărtășire a experiențelor și a cunoștințelor, prin exercițiul său, precum și prin cunoașterea pe care o poate procura (şi printre ale cărei surse limbajul se numără), limbajul s-a statornicit ca un comportament biosocial, de comunicare, proteic și polivalent, forțind orice gamă posibilă, de la superfluu la ludic, de la informațional la estetic și obținînd efecte multiple, de la cel de clichet (prin care se produc dezvoltări și acumulări dincolo de indivizi și de timp) la cel de factor de disoluție.

Toate acestea sînt rezultatele unor procese evolutive înlănțuite, la ale căror începuturi nu se întrezăreau nici măcar etapele intermediare.

\section{Bibliografie}

Corballis, M.C. (2003). From Hand to Mouth: The Gestural Origins of Language, în Christiansen, M.H. \& Kirby, S. (eds), Language Evolution, Oxford University Press, Oxford, p. 403-428, Crossref.

Corballis, M. C. (2007). How Language Evolved, în „Acta Psychologica Sinica”, 39 (3), p. 415-430, [online].

Corballis, M.C. (2009). Language as gesture, în „Human Movement Science”, 28 (5), p. 556-565, Crossref.

Corballis, M. C. (2009b). The evolution oflanguage, în „Annals of the New York Academy of Sciences”, 1156, p. 19-43, Crossref.

Corballis, M.C. (2010). Mirror neurons and the evolution of language, în „Brain and language”, 112 (1), p. 25-35, Crossref.

Corballis, M.C. (2013). Gestural theory of the origins of language, în Lefebvre, C., Comrie, B. \& Cohen, H. (eds), New Perspectives on the Origins of Language, John Benjamins Publishing Company, p. 171-184, Crossref.

Corballis, M. C. (2014a). Recursive Cognition as a Prelude to Language, în Lowenthal, F. \& Lefebvre, L. (eds), Language and Recursion, Springer, p. 27-36, Crossref.

Corballis, M.C. (2014b). The gradual evolution of language, în „Humana Mente: Journal of Philosophical Studies”, 7 (27), p. 39-60, [online].

Corballis, M.C. (2017). Language Evolution: A Changing Perspective, în „Trends in Cognitive Sciences”, 21 (4), p. 229-236, Crossref. 